\title{
BRAVING THE SEAS: THE SWIMMER IMAGE IN CONRAD'S FICTION
}

\author{
Narain Prasad Shukla \\ Hadhramout University, Yemen
}

\begin{abstract}
The purpose of this paper is to examine the recurrence of the image of a swimmer in the fiction of Joseph Conrad. The image appears at the key place of the narrative and constitutes its turning point. It functions in Conrad's fiction in two forms: as a metaphor for individual struggle against destiny, and as a device of characterisation. In both forms the image constitutes an instrument of integration of Conrad's works, which are otherwise widely different from one another in tone, texture, colouring and content.
\end{abstract}

Keywords: image, swimmer, destiny, metaphor

An image of a solitary swimmer left absolutely to his own devices occurs frequently in Conrad's fiction. The act of swimming represents a determination on the part of the swimmer to grapple with destiny in an effort to achieve his objective, and he swims assiduously without any support from anywhere. The swimmer is an individual who is cast in a certain predicament, and the watery expanse around him symbolises fate or particular circumstances which present a challenge to him. The man may either overcome destiny, or succumb to it, but he establishes his true worth in the process. Alternatively, the image is used to project the inner traits of a particular character, and it acquires a distinctive colouring in each case.

The image of a swimmer can be traced back to Conrad's correspondence with John Galsworthy. Conrad tells Galsworthy in a letter dated $11^{\text {th }}$ November 1901:

Say what you like, man lives in his eccentricities (so called) alone. They give a vigour to his personality which mere consistency can never do. One must explore deep and believe the incredible to find out the few particles of truth floating in an ocean of insignificance. ${ }^{1}$

In his fiction Conrad frequently uses the image as a simile and many of his protagonists are swimmers literally as well as figuratively. Unquestionably, it is up to the attitude of a hero whether he withstands the slings of fortune or gives in to them,

${ }^{1}$ Gérard Jean-Aubry, Joseph Conrad: Life and Letters, Vol. 1, Garden City, NY 1927, p. 301. 
which leaves a particular stamp on the protagonist and his fortunes in each case. In An Outcast of the Islands, Willems sees himself as a spent swimmer giving up when he surrenders to the charms of Aissa. He sees Aissa when he is marooned by Lingard in the jungle imbroglio of Sambir at Almayer's trading station as a punishment for his embezzlement at Macassar in the Malay Archipelago.

Conrad uses the undercurrent of the swimmer imagery to suggest the progression of Willems's thoughts as he is made to leave the station. Willems now comes to envy the native workmen at the station who have, through their labour, a place and purpose in the natural order of things: "The very savages around him strove, struggled, fought, worked [...]. And it was only himself that seemed to be left outside the scheme of creation in a hopeless immobility." ${ }^{2}$ Conrad gradually prepares us for Willems's approaching liaison with Aissa, the daughter of an old native who lives nearby. Willems is aware of his moral downgrading in effect of his involvement with the girl. The hopelessness of his situation is described as follows:

He struggled with the sense of a certain defeat [...] lost his footing [...] fell back into the darkness. With a faint cry and an upward throw of his arms he gave up as a tired swimmer: because the swamped craft is gone from under his feet: because the night is dark and the shore is far [...] because death is better than strife. ${ }^{3}$

Karain, the only swimmer in Tales of Unrest, shows an exhaustion which is more than physical. He is haunted by the ghost of Matara, which reappears after the death of an old sorcerer, who has laid the ghost to rest, and he swims off to the white man's ship alone at night in torrential rain, seeking deliverance from the vision: "the tormented weariness, the anger and the fear of a struggle against a thought, an idea [...] a shadow, a nothing, unconquerable and immortal, that preys upon life." Karain begs to be taken away beyond the reaches of the ghost that haunts him, and when he is turned down, he desperately asks the white men for a charm as he admires their ways and their queen (Victoria), whom he regards as a kind of goddess. He implores them to bequeath to him some of their strength, their unbelief. And "young Hollis," one of the white men, hits upon a way of giving it to him. He proceeds to fashion a talisman out of a piece of a ribbon and a Jubilee six-pence bearing the image of Queen Victoria. When Karain places it round his neck and is duly exhorted to "forget and be at peace", ${ }^{5}$ the sceptre of Matara is laid to rest the second time.

However, the way the white men deal with Karain is deeply ironic. The narrator's impulse to help Karain amounts to little more than bidding him to control himself: "You must abide with your people"- the narrator says. - "They need you." "The Ceremony of investing Karain with a sixpence-in itself an ironic comment on nineteenth century colonial practices-is regarded by all the white men as mere game.

\footnotetext{
${ }^{2}$ Joseph Conrad. An Outcast of the Islands. Collected Edition of the Works of Joseph Conrad, 21 Vols. London, 1946-55, p. 65.

${ }^{3}$ Ibid., pp. 80-81.

${ }^{4}$ Joseph Conrad. Tales of Unrest. Collected Edition. London, p. 23.

${ }^{5}$ Ibid., p. 51.

${ }^{6}$ Ibid., p. 43.
} 
However, the misgivings about both the talisman as an "engraved image" and the resultant shock to Karain's followers are quickly dismissed. The white men's primary concern is whether their trick works. None of them seems to feel any moral involvement in Karain's plight. It is as if the whites begin and end with the feeling that Karain as a Malay simply cannot be treated as they themselves might expect to be treated under similar circumstances. They are unable to think of the metaphysical import of Karain's predicament. To them he is a mere thing to be dealt with in the most expedient manner. And when Jackson later attaches a deeper significance to Karain's experience than to the bustling life of London, the narrator can hardly believe it. His smug concluding thought reaffirms the Englishman's casual conviction of superiority over Karain, and the world of the East.

The climax of the swimming image in Conrad is to be found in a passage from Lord Jim, where it is combined with a work image. Stein finds Jim excessively romantic and considers his attitude essentially incompatible with the realities of existence. He used to be a romantic himself but he abandoned this approach in favour of a realistic one. In consequence, he was able to capture the rare butterfly which had been eluding his grasp all along. According to Stein, Jim must find his way through ceaseless efforts and must not be diverted from his main course.

Stein considers human action as a means to individual fulfilment. In "Heart of Darkness," Marlow refers to work "as a chance to find yourself," 8 and Stein's advice to Jim is that he should take recourse to action as a means of realising his dream:

A man that is born falls into a dream like a man who falls into the sea. If he tries to climb out into the air as inexperienced people endeavour to do, he drowns [...] The way is to the destructive element submit yourself, and with the exertions of your hands and feet in the water make the deep, deep sea keep you up. ${ }^{9}$

In Nostromo the figure of a lonely swimmer is associated with the indefatigable human spirit in the article of the trying elemental forces. Nostromo's heroic swim is an act of exceptional bravery in the face of imminent danger and acquires special significance in the mind of Dr. Monygham when he approaches Nostromo after the latter's swim back from the empty lighter abandoned in the Placid Gulf:

Having had to encounter single handed during his period of eclipse many physical dangers, he [Dr. Monygham] was well aware of the most dangerous element common to them all: of the crushing paralysing sense of human littleness, which is what really defeats a man struggling with natural forces, alone, far from the eyes of his fellows. He was eminently fit to appreciate the mental image he made for himself of the Captaz [Nostromo] after hours of tension and anxiety, precipitated suddenly into the abyss of waters and darkness, without earth or sky, and confronting it not only with undismayed mind, but with sensible success. Of course, the man was an uncomparable swimmer [...] but the doctor judged that this instance testified to a still greater intrepidity of spirit. ${ }^{10}$

\footnotetext{
${ }^{7}$ Ibid., p. 48.

${ }^{8}$ Joseph Conrad. "Heart of Darkness." Collected Edition. London, p. 85.

${ }^{9}$ Joseph Conrad. Lord Jim. Collected Edition. London, p. 214.

${ }^{10}$ Joseph Conrad. Nostromo. Collected Edition. London, p. 433.
} 
Torn between his loyalty to his native friends Hassim and Immada, and to Mrs. Travers, Captain Lingard from The Rescue is a tragic example of a successful swimmer checked suddenly by unforeseen factors. Lingard stands committed to support his native friends to free their land from the Dutch occupation. However, when the time comes, he forgets all about it, and loses a great opportunity of uniting East and West. A sub-conscious racial upsurge deprives Lingard of a chance to extend his hand of friendship to the native princes. In this conflicting situation he is described as a racial and tragic surrender: "He felt like a swimmer, who in the midst of superhuman efforts to reach the shore perceives that the undertow is taking him to sea. He would go with the mysterious current; he would go swiftly [...] and see the end, the fulfilment both blissful and terrible." 11

Later in the same work, this image is applied to Hassim and Immada, who feel that Lingard has abandoned his plan to help them. Lingard lingers by negotiating a release of his fellow men trapped in Belerab's camp and the ring that Hassim sends to him as a token of their friendship never reaches him. The vision of friendship entertained by Hassim and Immada, ideal though it may seem, is mocked by the impossibility of its realization. Coming out of the lit cabin of Lingard's ship at night:

they entered the same darkness which had received, enveloped and hidden the troubled souls of Lingard and Edith, but to these two the light from which they had felt themselves driven away was now like the light of forbidden hopes: it had the awful and the tranquil brightness that a light burning on the shore has for an exhausted swimmer about to give himself up to the fateful sea. They looked back; it had disappeared. ${ }^{12}$

Several of Conrad's characters beleaguered by destiny commit suicide by drowning and a few meet their doom in an ironic way. In "The End of the Tether," aboard the sinking Sofala, Captain Whalley weights his body with the iron that has deflected the ship's course and caused her to founder. In response to the calls from the Sofala's crew to leap off and swim to them, he reflects that he could, indeed, swim and save himself. But, in fact, he has made up his mind to go down with the ship and he places additional weight in his pocket because he feels it "unseemly that a Whalley who had made up his mind to die, should be beguiled by chance into a struggle."13

Similarly, Decoud in Nostromo weights his body with some of the silver that has brought about his ruin, shoots himself so as to fall over the side of his small boat and disappears into the Placid Gulf, "swallowed up in the immense indifference of things." ${ }^{14}$ Ceasar Cervoni dies in a similar way in the "Tremolino" episode of The Mirror of the Sea. After the narrator deliberately wrecks the "Tremolino" to prevent the authorities from capturing it, Cesar, who has betrayed the ship, is dispatched by a blow from Dominic and drowns with a belt of stolen gold around his waist." 15

\footnotetext{
${ }^{11}$ Joseph Conrad. The Rescue. Collected Edition. London, p. 219.

${ }^{12}$ Ibid., p. 240.

${ }^{13}$ Joseph Conrad. Youth. Collected Edition. London, p. 333.

${ }^{14}$ Joseph Conrad. Nostromo. Collected Edition. London, p. 501, p. 26.

${ }^{15}$ Joseph Conrad. The Mirror of the Sea. Collected Edition, London, p. 181.
} 
In Victory the image of the drowning swimmer is taken out of its original context and applied to Axel Heyst, who has withdrawn to a remote island to escape the troubles of the world. Schomberg, the villainous hotel-keeper of Sourabaya, once remarks about Heyst: "I hope the fellow did go and drown himself." ${ }^{16}$ Heyst is actually living in a stoic detachment on the sequestered island of Samburan in consequence of his alienist attitude to life. He believes that society is the cause of all the troubles and so his escapist attitude is aimed at shunning the evils of the world. As Davidson, who recently spoke to Heyst during his visit to Samburan, views him:

He marched into the long grass and vanished. [...] all but the top of his white cork helmet, which seemed to swim in a green sea, as if it had sunk into the living depths of tropical vegetation, which is more jealous of men's conquests than the ocean, and which was about to close over the last vestiges of liquidated Tropical Belt Coal Company [...] A. Heyst, manager in the East. ${ }^{17}$

The first reference in Conrad's works to a swimmer who swims for a distant land which has some ideal significance for him occurs in "The Secret Sharer." Leggatt, the fugitive from excruciating justice, literally swims into and out of the story. He comes and goes through the watery element, unseen by any except the narrator, who, as captain of his own ship, takes Leggatt aboard and hides him. Leggatt tells the narrator:

I didn't seem to drown myself, I meant to swim till I sank [...] but that's not the same thing. I struck for another of these islands, and it was from that one that I first saw your riding light. Something to swim for [...] I couldn't see any stars low down because the coast was in the way, and I couldn't see the land either. [...] one might have been swimming in a confounded thousand feet deep cistern with no place for scrambling out anywhere. ${ }^{18}$

"The Secret Sharer" concludes on as happy a note as any in Conrad's stories, with Leggatt escaping: "a free man, a proud swimmer striking out for a new destiny." 19

"The Planter of Malata" is an articulation of the swimmer as an idealist and a romantic hero. Geoffrey Renouard, the self-willed, independent planter is heart-broken after being jilted by a coldly beautiful and even more self-willed woman. He commits suicide by setting off from the shore of an island plantation: "calmly to swim off beyond the confines of life $[\ldots]$ with a steady stroke $[\ldots]$ his eyes fixed on a star." ${ }^{\prime 20}$ This quotation echoes an earlier passage in the same story, which describes Renouard's swim back by night to his schooner as it lies at anchor off the shore of Malta. He has secretly swum ashore to make arrangements for the visitors he has on board, and his swim back to the ship is described in part as follows: "Renouard set his direction by a big star that, on the horizon, seemed to look curiously in his face [...]. There came a moment when it seemed to him that he must have swum beyond the confines of life. $[\ldots]$ looking at a star!" 21

\footnotetext{
${ }^{16}$ Joseph Conrad. Victory. Collected Edition. London, p. 26.

${ }^{17}$ Ibid., p. 29.

${ }^{18}$ Joseph Conrad. Twixt Land and Sea. Collected Edition. London, pp. 108-9.

${ }^{19}$ Ibid., p. 32.

${ }^{20}$ Joseph Conrad. Within the Tides. Collected Edition. London, p. 85.

${ }^{21}$ Ibid., p. 62.
} 
Flora de Barral in Chance is described as follows immediately after Captain Anthony has made his first impression upon her during their walk together near the Fynes' house: "That girl was [...] washing about with slack limbs in the ugly surf of life with no opportunity to strike out for herself, when suddenly she had been made to feel that there was somebody beside her in the bitter water."22 Flora had, in fact, been contemplating suicide and this depiction of her as a swimmer reflects the state of her mind.

To conclude, the figure of the swimmer thus holds a metaphysical as well as psychological significance for Conrad. In his novels and tales, the swimmer evolves into a universal symbol of a relentless crusader, an untiring venturer into distant lands, and an explorer of the fateful unknown.

\section{WORKS CITED}

Aubry Jean, G. Joseph Conrad: Life and Letters, 2 Vols., Garden City, NY 1927.

Conrad Joseph, Collected Edition of the Works of Joseph Conrad, 21 Vols., London 1946-55.

${ }^{22}$ Joseph Conrad. Chance. Collected Edition. London, p. 222. 